\title{
Analysis on the Training Mode of Logistics Management Applied Talents under the Background of "Internet + "
}

\author{
Yang Kang, a * \\ ${ }^{1}$ Wuhan Technology and Business University, Wuhan China \\ akangyang0301@163.com
}

Keywords: Internet +; Logistics Management; Applied talents

\begin{abstract}
As China enters into the era of "Internet + ", the educational reform in colleges and universities has also been pushed to the cusp of times. Faced with the new round of educational reform opportunities for development, it is a thorny issue that how to understand "Internet + " and explore a suitable "Internet + Education" path of development. In the era of big data and "Internet +", this paper analyzes the current situation and characteristics of the current training mode of logistics management talents, and puts forward corresponding countermeasures according to these characteristics.
\end{abstract}

\section{Introduction}

The rapid development of the Internet economy and the implementation of the "Internet +" strategy put higher demands on the training of logistics management talents in high education institutions. Big data is not only a huge amount of data, but also a kind of resource, which is a kind of data technology with the mode of thinking analysis. High education institutions should also keep pace with the times in the teaching research of the course. They should have big data thinking mode, be able to use big data technology to perform deeply analysis of teaching data and integrate "Internet + " era resources, and let the times to promote high education institution reform. The cultivation of applied talents emphasizes the combination of theory and practice. It not only pays attention to the education of students 'theoretical knowledge, but also emphasizes the cultivation of students' practical ability. At present, faced with the new round of education reform opportunities, the introduction of "Internet + " thinking into teaching practice and exploration of a practical and reasonable mode of "internet + education" talents training are the important topics in the teaching and research of all major colleges and universities at present.

\section{Analysis of Current Situation of Logistics Management Talents Training Modes in Chinese High education institutions}

Logistics management major is younger major, compared with other majors, talents training is not yet mature, especially for practical teaching. Overall, there are following problems in the training mode of logistics management major for colleges and universities in our country:

\section{(1) Teaching mode are out of line with practice}

The main characteristics of logistics management major is practicality, at current stage the traditional theory teaching is still being taken as the principal thing, and practice teaching is less, it is not conducive to cultivating students' practical and comprehensive application ability. In the era of "Internet +", all major colleges and universities are actively exploring the diversification of talents training mode, and broaden students' access to knowledge and information. Teachers in classroom teaching should pay more attention to guide students to learn knowledge skills related to knowledge points and improve their professionalism.

(2) Less emphasis on other courses in teaching.

In the time of "Internet + " era, all walks of life and the logistics industry are showing a trend of deep integration and development, but the lack of compound logistics talents has become a constraint to the development of the industry one of the main factors. At present, all colleges and universities' training mode is that more emphasis on logistic courses has been taken, and neglected the teaching of computer, 
English and modern operation software courses, which result students are proficient in professional courses, but poor in comprehensive practical ability, and cannot adapt to the "Internet + " era demand.

(3) Course system coverage needs to be improved

One of the important features of the era of "Internet Plus" is the development of cross-boundary integration. And this has become a new trend and an important innovation route for the development of the industry. The cross-boundary integration of the logistics industry and e-commerce has also been inevitable for the logistics industry to achieve sustainable development trend. At present, there are few courses related to e-commerce in the course system of logistics management in colleges and universities in China. As a result of that, teachers cannot embody the integration knowledge of e-commerce in teaching during the teaching process, leading to the lack of students' knowledge fusion and practical application.

(4) Lack of vocational qualification system.

Through the establishment of certification system, the evaluation criteria of "Internet + " applied talents can be formed, and the logistics management talents can be encouraged to participate in this certification examination to continuously improve their professional knowledge and comprehensive quality. Currently in the field of logistics management, there is no national unified certification exam which has high reputation. The absence of certification system lead current logistics management talents lack of understanding for the "application-type" content, cannot use the certification platform as well as the ways to guide the logistics management talents continue to expand their own comprehensive quality.

\section{The Characteristics of Logistics Management talents under the Background of "Internet +"}

At present, the discipline system of logistics management needs to be perfected, the learning content is relatively boring, and the lack of training facilities make it hard for students to expand their capabilities. "Internet + " under the background of logistics management talents should keep pace with the times, should have the following characteristics:

(1) "Internet +" Emphasizes International View of Logistics Talents

With the advent of the "Internet +" era, the proposed "One Belt and One Road" strategy requires our logistics enterprises to have the strength of international operations. Internationalized logistics companies integrate the global outsourcing and inward logistics modules of their customers' enterprises with their local warehousing and distribution systems to achieve convergence between the upstream and downstream of the supply chain. This requires that business talents possess international expertise, strong professional knowledge of overseas logistics, cross-boundary logistics, international trade, overseas market laws and the application of warehouse management mode, etc., and should understand the relevant systematic operation of international logistics.

\section{(2) "Internet + " requires logistics talents familiar with a variety of Internet technologies}

"Internet + " is characterized by the use of emerging technologies such as big data, cloud computing and mobile internet, all of which have contributed to the rise of the smart logistics industry. Smart Logistics greatly enhance the efficiency of resource utilization, to achieve all aspects of logistics industry information sharing and efficient allocation of social resources. Therefore, modern logistics talents not only need to be familiar with the main information technology of logistics, but also have some new technologies of Internet.

(3) "Internet + " provides a new platform for college students' innovation and entrepreneurship

"Internet + " is driving the tide of entrepreneurship and innovation in China, and the logistics industry is no exception. On the one hand, it provides a bigger and lower threshold of innovation and entrepreneurship platform for college students. On the other hand, it also puts forward higher requirements on the entrepreneurial ability of college students. The college education must seriously consider how to cultivate students' comprehensive quality in the process of education, such as innovation, pragmatism and so on.

The advent of the Big Data era has made it possible for us to fully quantify students. We can collect and organize students' information in the process of teaching, analyze their learning status, personal 
abilities, and professional accomplishments and so on. We can strengthen pre-school, mid-school and post-school intervention and monitoring so that we can understand and solve problems in time, to teach students according to their aptitude.

\section{Strategy of Training Applied Talents in Logistics Management Based on "Internet +" in Colleges and Universities}

Under the background of "Internet $+"$, the cultivation of applied talents of logistics management in colleges and universities in our country can be carried out from three aspects: the position of talents cultivation, the reform of classroom teaching and the teaching of logistics practice so as to ensure the validity and applicability of the training mode of applied logistics management talents.

\section{(1) The Position of Talents Cultivation}

The competition of today's enterprises is the competition of talents. Talent is the most important resource of an enterprise. In response to the opportunities and challenges that the "Internet + " brings to the logistics industry, the major of logistics management in colleges and universities should make corresponding adjustments in the mode of talents training, and gradually shift from the traditional application orientation to advanced application and compound talents. Advanced applied and complex talents are high-level professionals in professional technology. In addition to having solid theoretical foundation of logistics operation and management, computer and information, finance and so on, and having good foreign language ability, it is also necessary to establish an international concept, service concept, enhance practice and entrepreneurial innovation ability, learning ability and so on. Logistics talents training should pay attention to the sensitivity of students to the contemporary advanced technology, familiar with the big data, Internet of things, cloud computing and other emerging technologies and methods.

(2) Using "Internet +" to Promote the Reform of Colleges' Classroom Teaching

With the advent of "Internet + "era, the MOOC has promoted the reform of teaching methods in colleges and realized the reversal of classes. At present, undergraduates are a generation with Internet growth. Compared with the fixed teaching mode in which students teach lectures by traditional teachers, "Internet $+"$ college classroom teaching pays more attention to user experience, emphasize the exploration of new teaching methods that benefit knowledge transfer from big data. In general, the knowledge, behavior modeling and teaching analysis of learners can be used to mine the data generated in the process of student learning and optimize the teaching mode. At the same time, the status of teachers and students is gradually changing, allowing students to become the protagonists of the class. On the one hand, students should have the awareness of learning resources from the Internet, the ability to quickly search useful knowledge from the vast knowledge, and change passive change to autonomy. On the other hand, teachers can understand students' learning through analyzing online learning behaviors. Accurately locate their own teaching tasks, and make teaching content more flexible.

(3) Innovate the Practical Teaching of Logistics in Universities Based on "Internet + "

\section{Strategy}

In "Internet + "era, the traditional cultivation mode of logistics management talents must continually to innovate, and to achieve" Internet + logistics teaching practice "innovative fusion mode. In the process of teaching, teachers should guide students to actively apply integrated technology to solve practical problems and optimize the operation process so that students can understand the actual application effect of intelligent logistics and improve their practical ability, and continuously improve their comprehensive quality from practice. Make effort to let the trained talents have the comprehensive qualities and capabilities, in terms of practical application ability, information system development capability, big data integration capability, teamwork capability and innovation ability that meet the development requirements of the new era. 


\section{Conclusions}

In a word, as the cradle of training high-quality talents to support the development of the logistics industry, the logistics management major in colleges and universities should also follow the development of the times and constantly innovate the current talents training mode. The training of applied logistics talents should be put on a strategic level, in the "Internet + " era, the rapid development of the logistics industry, talent training is particularly important. The training mode of logistics management talents in colleges and universities should fully integrate the needs of social talents in colleges and universities, keep pace with the times, apply the Internet thinking to the training mode and cultivate comprehensive logistics talents. At the same time, for the opportunities brought by the new era, logistics students should take a positive attitude and be good at utilizing various Internet resources to enhance their own competitiveness to response the fierce competition in the market.

\section{Acknowledgements}

Project Name: Teaching research project of Wuhan Technology and Business University Project Number: 2012Y07

\section{References}

[1] F. Meng, Research on Talents Training Mode of Applied Logistics Management, 2014 International Conference on Global Economy, Finance and Humanities Research (GEFHR 2014).

[2] X.D.Zhai, Training for Applied Port Logistics Management Talents Based on Concept of CDIO Education, 2015 International Conference on Social Science,Education Management and Sports Education(SSEMSE 2015).

[3] M. Mao, J. Zhang and C. Wang, Construction and Implementation of Flipped Classroom Teaching Mode in Logistics Management Courses in the era of "Internet +", Logistics Engineering and Management, 2017(6):216.(In Chinese)

[4] M. Du, Research and Practice of Training Mode of Logistics Management Major in Open Education, Logistics Engineering and Management, 2015(04):158-163. (In Chinese)

[5] Peng L. Cost heterogeneity and peak prediction in collective actions [J]. Expert Systems With Applications, 2017, 79: 130-139. 